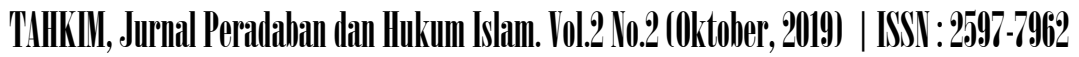

\title{
ANALISIS HUKUM TENTANG UPAYA MEDIATOR DALAM MEMINIMALISIR JUMLAH PERCERAIAN DI PENGADILAN AGAMA KELAS 1A KABUPATEN INDRAMAYU (Studi Kasus Perkara Perceraian Tahun 2016-2018)
}

\author{
Siska Lis Sulistiani, Encep Abdul Rojak, Vera Fadillah Marufin \\ Fakultas Syari'ah, Universitas Islam Bandung \\ ummufathir@gmail.com, abd.rojak19@gmail.com, Veyjeh02@gmail.com
}

\begin{abstract}
ABSTRAK
Dalam Peraturan Mahkamah Agung Nomor 1 Tahun 2008 tentang Prosedur Mediasi di Pengadilan, mediasi adalah cara penyelesaian sengketa melalui proses perundingan untuk memperoleh kesepakatan para pihak dengan dibantu oleh mediator. Mediator adalah pihak netral yang dapat membantu para pihak dalam proses perundingan. Dalam penelitian tersebut bertujuan untuk mengetahui bagaimana upaya mediator dalam meminimalisir jumlah perceraian di Pengadilan Agama Indramyu. Dalam penelitian ini metode yang digunakan adalah metode kualitatif dengan pendekatan yuridis normatif dengan kajian penelitian lapangan (field research) di Pengadilan Agama Indramayu. Teknik pengumpulan data yang penulis gunakan ada tiga yaitu wawancara (interview),dokumentasi, dan kajian kepustakaan kemudian dianalisis dengan metode deskriptif. Hasil akhir dari penelitian ini adalah bahwa peranan mediator dalam meminimalisir jumlah perceraian di Pengadilan Agama Indramayu sudah sesuai dengan prosedur mediasi dalam PerMA No 1 Tahun 2016. Mediator melakukan upaya dengan mediasi, muasabah diri untuk kedua belah pihak,memberitahukan akibat hukum yang terjadi dan memberikan solusi dengan memberi kesempatan kedua belah pihak menceritakan masalahnya. Langkah ini merupakan salah satu cara untuk meminimalisir namun tidak setiap mediasi menghasilkan hasil yang maximal. Maka dari itu mediator harus mengeluarkan trobosan terbaru dalam memediasi dan menjadikan mediator yang kreatif dan inovatif.
\end{abstract}

Kata Kunci: Mediator, Mediasi, dan Perceraian.

\section{ABSTRACT}

In the Supreme Court Regulation Number 1 of 2008 concerning Mediation Procedures in Courts, mediation is a method of resolving disputes through the negotiation process to obtain agreement between the parties assisted by mediators. The mediator is a neutral party who can help the parties in the negotiation process. In this study the aim was to find out how the mediators tried to minimize the number of divorces in the Indramyu Religious Court. In this study the method used is a qualitative method with a normative juridical approach with field research in the Indramayu Religious Court. There are three data collection techniques that the author uses, namely interviews, documentation, and literature review and then analyzed using descriptive 
methods. The final result of this study is that the role of mediators in minimizing the number of divorces in the Indramayu Religious Court is in accordance with mediation procedures in PerMA No. 1 of 2016. Mediators make efforts with mediation, satisfy themselves for both parties, notify legal consequences that occur and provide solutions by giving both parties a chance to tell the problem. This step is one way to minimize but not every mediation produces maximum results. Therefore, the mediator must issue the latest breakthroughs in mediating and making creative and innovative mediators.

Keywords: Mediator, Mediation, and Divorce.

\section{A. PENDAHULUAN}

Perkawinan merupakan sunatullah yang umum dan berlaku pada semua makhluk-Nya, baik pada manusia, hewan maupun tumbuh-tumbuhan. Ia adalah salah satu cara yang dipilih oleh Allah SWT sebagai jalan bagi makhluk-Nya untuk berkembang biak dan melestarikan hidupnya. ${ }^{1}$

Di dalam Islam diatur segala macam perbuatan yang dilakukan oleh manusia dalam hal ibadah, muamalah dan munakahat. Hukum atau perundang-undangan yang khusus membahas pernikahan (perkawinan) ada di dalam fikih munakahat. ${ }^{2}$

Akan Tetapi, berdasarkan data yang diperoleh dari Pengadilan Agama Indramayu, angka perceraian semakin tinggi. Yaitu pada tahun 2016 mencapai 7.594 perkara, 2017 mencapai 7.665 perkara dan pada tahun 2018 mencapai 7.776 perkara. Ternyata di Pengadilan Agama Indramayu setiap tahunnya itu meningkat. Namun sebelum menginjak pada tahap persidangan adanya upaya perdamaian terlebih dahulu. ${ }^{3}$

Berdasarkan latar belakang yang telah diuraikan, maka tujuan dalam penelitian ini adalah sebagai berikut:

1. Untuk mengetahui mediasi dalam perspektif Islam

2. Untuk mengetahui upaya mediator dalam melaksanakan mediasi di Pengadilan Agama Indramayu

3. Untuk mengetahui analisis hukum upaya mediator untuk meminimalisir jumlah perceraian di Pengadilan Agama Indramayu.

\footnotetext{
${ }^{1}$ S.Abidin dan Aminuddin,Fiqh Munakahat 1, (Bandung: Pustaka Setia,1999),hlm.9.

${ }^{2}$ Siska Lis Sulistiani,Kedudukan Hukum Anak Hasil Perkawinan Beda Agama Menurut Hukum Positif dan Hukum Islam,(Bandung: Refika Aditama,2015),hlm.9.

3 Wawancara dengan Bapak Yayan, Mediator Pengadilan Agama Indramayu, di Indramayu tanggal 8 Maret 2019.
} 
Metode yang digunakan adalah deskriptif secara kualitatif dengan pendekatan yuridis normative, dengan menggunakan sumber dan jenis data sekunder, melalui studi literature dan wawancara di lokasi penelitian yaitu PA Indramayu.

\section{B. PEMBAHASAN}

\section{Landasan Teori}

Apabila usaha perdamaian yang diserahkan kepada kedua suami isteri tidak memperoleh hasil, maka usaha perdamaian selanjutnya dialihkan dan diserahkan kepada dua orang juru damai, masing-masing dari keluarga pihak suami dan dari keluarga isteri. $^{4}$

Usaha mendamaikan merupakan prioritas utama dan jika berhasil maka hal tersebut dipandang adil sebab dapat mengakhiri sengketa tanpa ada pihak yang merasa dikalahkan atau dimenangkan, sehingga tetap terjaganya kekeluargaan dan kerukunan. Jika usaha perdamaian itu tidak berhasil, barulah proses pemeriksaan perkara dilanjutkan. $^{5}$

Pada Pengadilan Agama istilah perdamaian lebih dikenal dengan mediasi yang berarti penyelesaian sengketa melalui proses perundingan para pihak dengan dibantu oleh mediator. ${ }^{6}$ Dalam Islam perdamaian sering disebut dengan Islah dan Tahkim. Namun, islah lebih condong kepada fungsi mediasi tersebut. Perdamaian lebih di kenal dengan Tahkim yang berarti juru damai. Yang menjadi dasar hukum tahkim dalam syari'at Islam adalah firman Allah dalam Q.S An-Nisa:35.

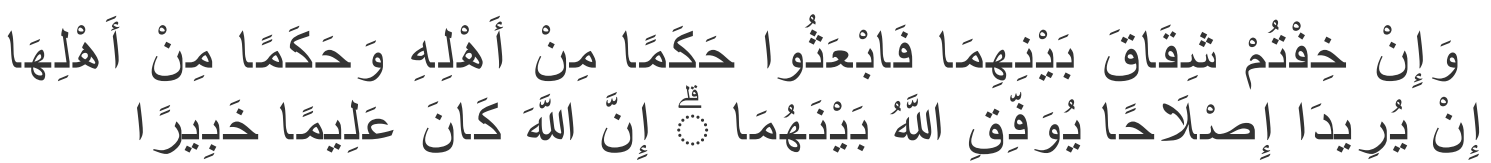

"Dan jika kamu khawatirkan ada persengketaan antara keduanya, maka kirimlah seorang hakam dari keluarga laki-laki dan seorang hakam dari keluarga perempuan. Jika kedua orang hakam itu bermaksud mengadakan perbaikan, niscaya Allah memberi taufik kepada suami-isteri itu. Sesungguhnya Allah Maha Mengetahui lagi Maha Mengenal".

\footnotetext{
${ }^{4}$ Djamil Latif, Aneka Hukum Perceraian Di Indonesia,Jakarta: Ghalia Indonesia, 1981,hlm.32.

5 Abdul Manan,Putusan Perdamaian dan Penerapannya di Pengadilan Agama, Mimbar hukum,No.35 tahun VIII Nov-Des 1997,hlm.15.

${ }^{6}$ Pasal 1 ayat (6) PerMA No 02 Tahun 2003, Tentang Prosedur Mediasi di Pengadilan.
} 
Sifat dan bentuk dalam penyelesaian sengketa yang dilakukan lembaga arbitrase lebih cenderung memilih cara kekeluargaan dan perdamaian. Dalam Q.S An-Nisa:127 ditegaskan bahwa "berdamai itu lebih baik".

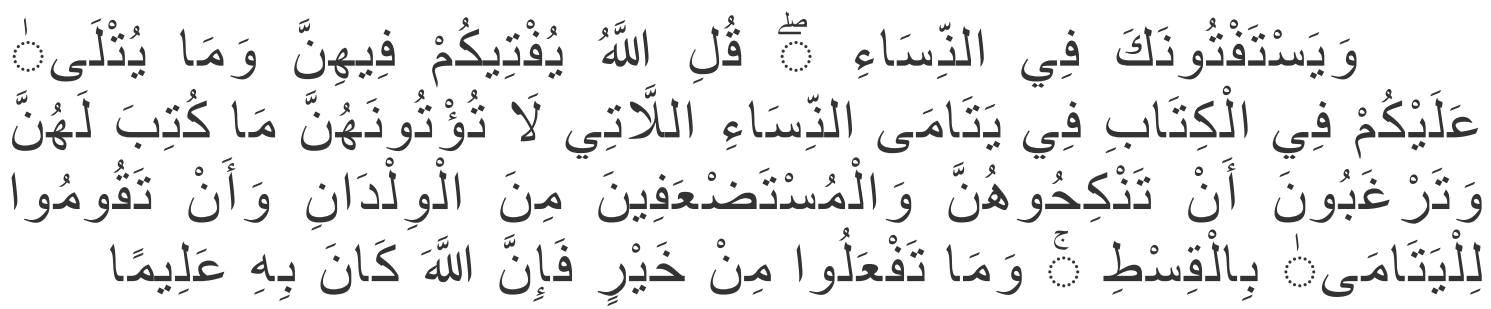

“ Dan mereka minta fatwa kepadamu tentang para wanita. Katakanlah: "Allah memberi fatwa kepadamu tentang mereka, dan apa yang dibacakan kepadamu dalam Al Quran (juga memfatwakan) tentang para wanita yatim yang kamu tidak memberikan kepada mereka apa yang ditetapkan untuk mereka, sedang kamu ingin mengawini mereka dan tentang anak-anak yang masih dipandang lemah. Dan (Allah menyuruh kamu) supaya kamu mengurus anak-anak yatim secara adil. Dan kebajikan apa saja yang kamu kerjakan, maka sesungguhnya Allah adalah Maha Mengetahuinya”.

Dan teori lainnya yang terkait dengan mediasi yaitu, teori Islah, teori system hukum dan teori equitable dan legal remides.

Teori Ishlah bersumber dari al-Quran. Ishlah disebut dalam beberapa ayat di dalam al-quran sebagai berikut:

1. Ishlah antar sesama muslim yang bertikai dan antara pemberontak (muslim) dan pemerintah (muslim) yang adil; Q.S. al-Hujurat:9-10,

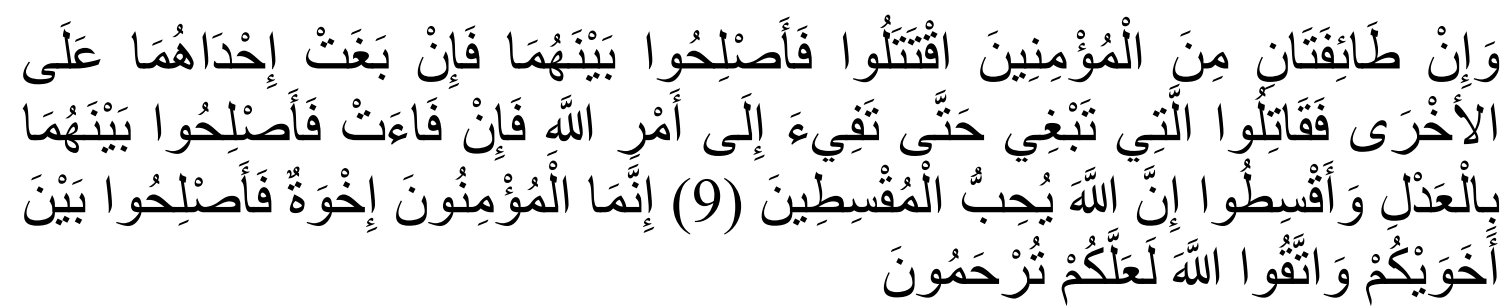

"Dan jika ada dua golongan dari orang-orang mukmin berperang, maka damaikanlah antara keduanya. Jika salah satu dari kedua golongan itu berbuat aniaya terhadap golongan yang lain, maka perangilah golongan yang berbuat aniaya itu sehingga golongan itu kembali kepada perintah Allah; jika golongan itu telah kembali (kepada perintah Allah), maka damaikanlah antara keduanya dengan adil, dan berlaku adillah. Sesungguhnya Allah menyukai orang-orang yang berlaku adil. Sesungguhnya orang- 
orang mukmin adalah bersaudara, karena itu damaikanlah antara kedua saudaramu dan bertakwalah kepada Allah supaya kamu mendapat rahmat.."

2. Ishlah antara suami-isteri yang di ambang perceraian; dengan mengutus alhakam (juru runding) dari kedua belah pihak; Q.S. al-Nisa:35. dan lainlain.

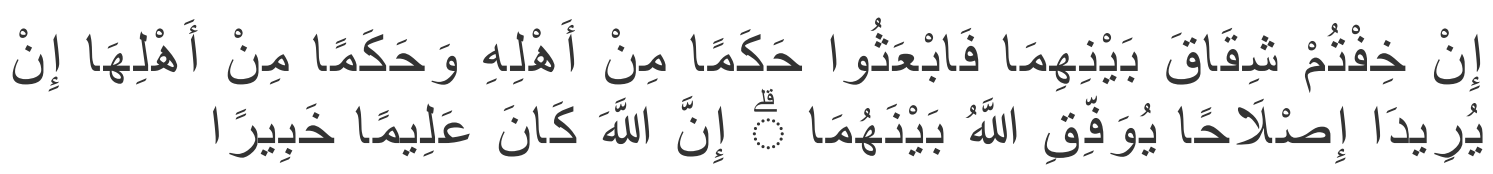

"Dan jika kamu khawatirkan ada persengketaan antara keduanya, maka kirimlah seorang hakam dari keluarga laki-laki dan seorang hakam dari keluarga perempuan. Jika kedua orang hakam itu bermaksud mengadakan perbaikan, niscaya Allah memberi taufik kepada suami-isteri itu. Sesungguhnya Allah Maha Mengetahui lagi Maha Mengenal."

3. Ishlah memiliki nilai yang sangat luhur dalam pandangan Allah, yaitu pelakunya memperoleh pahala yang besar Qs. al-Nisa: 114.

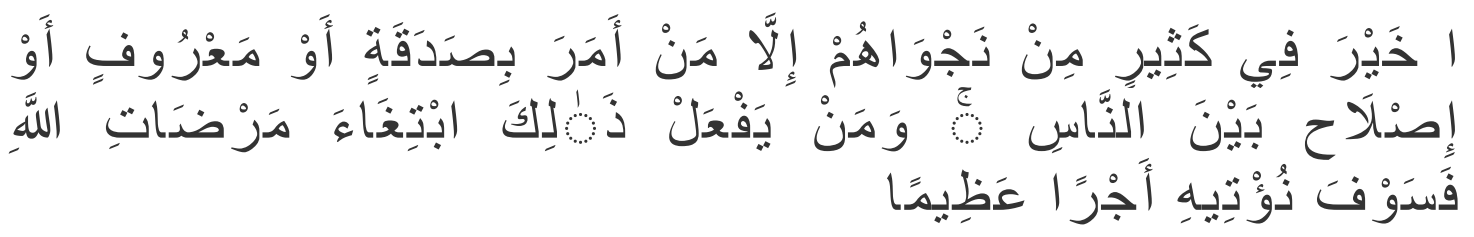

"Tidak ada kebaikan pada kebanyakan bisikan-bisikan mereka, kecuali bisikan-bisikan dari orang yang menyuruh (manusia) memberi sedekah, atau berbuat ma'ruf, atau mengadakan perdamaian di antara manusia. Dan barangsiapa yang berbuat demikian karena mencari keridhaan Allah, maka kelak Kami memberi kepadanya pahala yang besar".

4. Ishlah itu baik, terutama ishlah dalam sengketa rumah tangga Qs. an-nisa: 128.

Selanjutnya, teori sistem hukum oleh Lawrence M. Friedman menyebutkan bahwa sistem hukum terdiri atas perangkat struktur hukum, substansi hukum (perundangundangan) dan kultur hukum atau budaya hukum. Ketiga komponen ini mendukung berjalannya sistem hukum disuatu negara. Secara realitas sosial, keberadaan sistem hukum yang terdapat dalam masyarakat mengalami perubahan-perubahan sebagai 
akibat pengaruh, apa yang disebut dengan modernisasi atau globalisasi baik itu secara evolusi maupun revolusi ${ }^{7}$.

Hukum sebagai alat untuk mengubah masyarakat atau rekayasa sosial tidak lain hanya merupakan ide-ide yang ingin diwujudkan oleh hukum itu. Untuk menjamin tercapainya fungsi hukum sebagai rekayasa masyarakat kearah yang lebih baik, maka bukan hanya dibutuhkan ketersediaan hukum dalam arti kaidah atau peraturan, melainkan juga adanya jaminan atas perwujudan kaidah hukum tersebut ke dalam praktek hukum, atau dengan kata lain, jaminan akan adanya penegakan hukum (law enforcement) yang baik ${ }^{8}$. Bekerjanya hukum bukan hanya merupakan fungsi perundangundangannya belaka, melainkan aktifitas birokrasi pelaksananya ${ }^{9}$. Unsurunsur tersebut menurut Lawrence M. Friedman sebagai faktor penentu apakah suatu sistem hukum dapat berjalan dengan baik atau tidak ${ }^{10}$. Soerjono Soekanto, mengatakan ketiga komponen ini merupakan bagian faktor-faktor penegakan hukum yang tidak bisa diabaikan karena jika diabaikan akan menyebabkan tidak tercapainya penegakan hukum yang diharapkan ${ }^{11}$. Teori ini digunakan sebagai pisau analisis adalah karena sangat tepat digunakan untuk melihat dan memudahkan pemecahan masalah yang ada dimana hukum pada penerapan proses peradilan

Adapun Teori equitable and legal remedies Teori hukum ini dikemukakan oleh Lucy V. Kazt (1984: 588), yaitu keberhasilan proses penyelesaian sengketa alternatif melalui mediasi dikarenakan adanya "equitable and legal remedies" yang memberikan adanya kesederajatan yang sama dan penggantian kerugian secara hukum yang harus dihormati oleh para pihak. Para pihak mempunyai keyakinan bahwa penyelesaian sengketa melalui mediasi akan mendapat remedy for damages bagi mereka dengan win-win solution bukan win-lose solution. Di sini, para pihak "sama-sama menang" tidak saja dalam arti ekonomi atau keuangan, melainkan termasuk juga kemenangan moril dan reputasi (nama baik dan kepercayaan).

\footnotetext{
${ }^{7}$ Saifullah, Refleksi Sosiologi Hukum, (Bandung: Refika Aditama, 2007), hlm. 26

${ }^{8}$ Munir Fuady, Aliran Hukum Kritis : Paradigma Ketidakberdayaan Hukum, (Bandung: PT. Citra Aditya Bakti, 2003), hlm. 40

${ }_{9}^{9}$ Achmad Ali (I), Keterpurukan Hukum Di Indonesia, (Jakarta: Ghalia Indonesia, 2002), hlm. 97

${ }^{10} \mathrm{I}$ bid, hlm. 9

11 Soerjono Soekanto, Faktor-Faktor Yang Mempengaruhi Penegakan Hukum, (Jakarta: Rajawali, 1983), hlm. 5
} 


\section{Hasil Penelitian}

Berikut gambaran rekap jumlah dan tingkat keberhasilan mediasi di Pengadilan Agama Indramayu pada tahun 2016, digambarkan pada tabel di bawah ini:

\begin{tabular}{|c|c|c|c|c|c|}
\hline \multirow[b]{3}{*}{ NO } & \multirow[b]{3}{*}{ Bulan } & \multirow{3}{*}{$\begin{array}{c}\text { Jumlah } \\
\text { Jumlah } \\
\text { Perkara } \\
\text { yang Di } \\
\text { Mediasi }\end{array}$} & Jumlah & \multicolumn{2}{|c|}{ Laporan Penyelesaian Mediasi } \\
\hline & & & \multicolumn{3}{|c|}{ Laporan Penyelesaian Mediasi } \\
\hline & & & $\begin{array}{c}\text { Tidak } \\
\text { Berhasil }\end{array}$ & Berhasil & Gagal \\
\hline 1 & 2 & 5 & 6 & 7 & 8 \\
\hline 1 & JANUARI & 48 & 48 & & \\
\hline 2 & PEBRUARI & 41 & 41 & & \\
\hline 3 & MARET & 42 & 42 & & \\
\hline 4 & APRIL & 45 & 45 & & \\
\hline 5 & MEI & 48 & 48 & & \\
\hline 6 & JUNI & 36 & 36 & & \\
\hline 7 & JULI & 17 & 17 & & \\
\hline 8 & AGUSTUS & 33 & 33 & & \\
\hline 9 & SEPTEMBER & 43 & 43 & & \\
\hline 10 & OKTOBER & 38 & 38 & & \\
\hline 11 & NOPEMBER & 51 & 51 & & \\
\hline 12 & DESEMBER & 40 & 40 & - & - \\
\hline & Jumlah & 482 & 482 & 0 & 0 \\
\hline
\end{tabular}

Tabel 4

Rekap Jumlah dan Tingkat Keberhasilan Mediasi di Pengadilan Agama Indramayu Tahun 2016.

Adapun gambaran rekap jumlah dan tingkat keberhasilan mediasi di Pengadilan Agama Indramayu pada tahun 2017, digambarkan pada tabel di bawah ini: 


\begin{tabular}{|c|c|c|c|c|c|c|}
\hline & & & & $\begin{array}{c}\text { Tidak } \\
\text { Berhasil }\end{array}$ & Berhasil & Gagal \\
\hline 1 & 2 & 4 & 5 & 6 & 7 & 8 \\
\hline 1 & JANUARI & 834 & 44 & 44 & - & - \\
\hline 2 & PEBRUARI & 599 & 47 & 47 & & \\
\hline 3 & MARET & 678 & 42 & 42 & & \\
\hline 4 & APRIL & 659 & 34 & 34 & & \\
\hline 5 & MEI & 710 & 53 & 53 & & \\
\hline 6 & JUNI & 344 & 36 & 36 & & \\
\hline 7 & JULI & 1,069 & 31 & 31 & & \\
\hline 8 & AGUSTUS & 744 & 57 & 44 & 3 & \\
\hline 9 & SEPTEMBER & 671 & 42 & 42 & & \\
\hline 10 & OKTOBER & 774 & 50 & 49 & 1 & \\
\hline 11 & NOPEMBER & 644 & 45 & 44 & 1 & \\
\hline 12 & DESEMBER & 492 & 36 & 36 & & \\
\hline & JUMLAH & 7,726 & 481 & 466 & 5 & \\
\hline
\end{tabular}

Tabel 5

Rekap Jumlah dan Tingkat Keberhasilan Mediasi Di PA Indramayu Tahun 2017

Sedangkan gambaran rekap jumlah dan tingkat keberhasilan mediasi di Pengadilan Agama Indramayu pada tahun 2018, digambarkan pada tabel di bawah ini:

\begin{tabular}{|c|c|c|c|c|c|c|c|c|}
\hline \multirow[b]{2}{*}{ NO } & \multirow[b]{2}{*}{ BULAN } & \multirow{2}{*}{$\begin{array}{c}\text { Perkara } \\
\text { Diterima } \\
\text { Bulan } \\
\text { ini }\end{array}$} & \multirow{2}{*}{$\begin{array}{c}\text { Jumlah } \\
\text { Perkara } \\
\text { yang } \\
\text { tidak } \\
\text { bisa di } \\
\text { Mediasi }\end{array}$} & \multirow{2}{*}{$\begin{array}{l}\text { Jumlah } \\
\text { Perkara } \\
\text { yang Di } \\
\text { Mediasi }\end{array}$} & \multicolumn{3}{|c|}{$\begin{array}{c}\text { Laporan Penyelesaian } \\
\text { Mediasi }\end{array}$} & \multirow{2}{*}{$\begin{array}{c}\text { Masih } \\
\text { dalam } \\
\text { Proses } \\
\text { Mediasi }\end{array}$} \\
\hline & & & & & $\begin{array}{c}\text { Tidak } \\
\text { Berhasil }\end{array}$ & Berhasil & Gagal & \\
\hline 1 & 2 & 4 & 5 & 6 & 7 & 8 & 9 & 10 \\
\hline 1 & JANUARI & 37 & 0 & 37 & 28 & 1 & 0 & 8 \\
\hline 2 & PEBRUARI & 32 & 0 & 40 & 32 & 0 & 0 & 8 \\
\hline 3 & MARET & 35 & 0 & 43 & 28 & 0 & 0 & 15 \\
\hline 4 & APRIL & 44 & 0 & 59 & 51 & 0 & 0 & 8 \\
\hline 5 & MEI & 28 & 0 & 36 & 32 & 0 & 0 & 4 \\
\hline
\end{tabular}




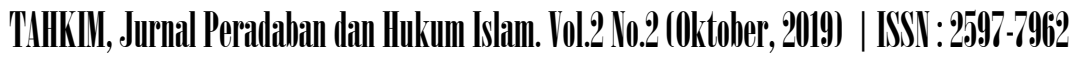

\begin{tabular}{||c|c|c|c|c|c|c|c|c|}
6 & JUNI & 19 & 0 & 23 & 14 & 0 & 0 & 9 \\
\hline 7 & JULI & 43 & 0 & 52 & 43 & 0 & 0 & 9 \\
\hline 8 & AGUSTUS & 54 & 0 & 63 & 51 & 0 & 0 & 12 \\
\hline 9 & SEPTEMBER & 33 & 0 & 45 & 37 & 1 & 0 & 7 \\
\hline 10 & OKTOBER & 56 & 0 & 63 & 48 & 1 & 0 & 14 \\
\hline 11 & NOPEMBER & 54 & 0 & 68 & 54 & 0 & 0 & 14 \\
\hline 12 & DESEMBER & 56 & 0 & 70 & 60 & 1 & 0 & 9 \\
\hline \multicolumn{2}{|c|}{ JUMLAH } & 491 & $\mathbf{0}$ & $\mathbf{5 9 9}$ & $\mathbf{4 7 8}$ & $\mathbf{4}$ & $\mathbf{0}$ & $\mathbf{1 1 7}$ \\
\hline
\end{tabular}

Tabel 6

Rekap Jumlah dan Tingkat Keberhasilan Mediasi Di Pengadilan Agama Indramayu Tahun 2018

Dari ketiga tabel tersebut terkait rekap keberhasilan mediasi dari tahun 20162018 menandakan bahwa sebagian besar tidak berhasil karena ada faktor lain diluar kuasa mediator yaitu dari kedua belah pihak itu sendiri.

Pelaksanaan mediasi memang sudah diterapkan di Pengadilan Agama Indramayu berdasarkan dengan prosedur mediasi dalam PerMA No 1 Tahun 2016, akan tetapi tingkat keberhasilan mediasi khususnya perceraian masih sangat rendah. Upaya yang dilakukan oleh mediator dalam melaksanakan mediasi yaitu: pertama memberikan nasehat-nasehat kepada kedua belah pihak yang berpekara untuk mencabut perkaranya, memberitahukan akibat hukum yang akan terjadi, melaksanakan mediasi sesuai dengan peraturan yang berlaku. Selain itu, upaya mediator dalam meminimalisir jumlah perceraian di pengadilan Agama Indramayu yaitu: tahap sesudah berumah tangga, jika terjadi perselisihan sebelum melanjutkan perceraian maka harus melalui proses mediasi,melakukan muasabah diri, dan memberitahu akibat hukum apa saja yang terjadi apabila perceraian itu terjadi.

Menurut pengamatan penulis terkait upaya mediator dalam meminimalisir jumlah perceraian ini kurang adanya trobosan baru dalam melakukan upaya mediasi dan kurangnya kreatif dan inovatif dari mediator dalam memediasi. 


\section{SIMPULAN}

Berdasarkan hasil penelitan mengenai analisis hukum upaya mediator dalam meminimalisir jumlah perceraian di Pengadilan Agama Indramayu, maka dapat disimpulkan sebagai berikut:

1. Dalam Islam perdamaian lebih dikenal dengan Tahkim. Bahwa Tahkim adalah mengangkat seseorang sebagai wasit atau juru damai.

2. Upaya yang dilakukan oleh mediator dalam melaksanakan mediasi yaitu: pertama memberikan nasehat-nasehat kepada kedua belah pihak yang berpekara untuk mencabut perkaranya, memberitahukan akibat hukum yang akan terjadi, melaksanakan mediasi sesuai dengan peraturan yang berlaku.

3. Upaya mediator dalam meminimalisir jumlah perceraian di pengadilan Agama Indramayu yaitu: tahap sesudah berumah tangga, jika terjadi perselisihan sebelum melanjutkan perceraian maka harus melalui proses mediasi,melakukan muasabah diri, dan memberitahu akibat hukum apa saja yang terjadi apabila perceraian itu terjadi.

\section{DAFTAR PUSTAKA}

Ali, Achmad. (2002). Keterpurukan Hukum Di Indonesia, Jakarta: Ghalia Indonesia. Data Mediasi Pengadilan Agama Kabupaten Indramayu 
Fuady, Munir . (2003). Aliran Hukum Kritis : Paradigma Ketidakberdayaan Hukum, Bandung: PT. Citra Aditya Bakti.

Latif,D.(1997). Aneka Hukum Perceraian Di Indonesia,Jakarta: Ghalia Indonesia, 1981,hlm.32.

Manan,,Abdul. Putusan Perdamaian dan Penerapannya di Pengadilan Agama, Mimbar hukum,No.35 tahun VIII Nov-Des.

Saifullah. (2007). Refleksi Sosiologi Hukum, Bandung: Refika Aditama.

S, Abidin. dan Aminuddin,(1999).Fiqh Munakahat 1,Bandung: Pustaka Setia.

Sulistiani,S.L.(2015).Kedudukan Hukum Anak Hasil Perkawinan Beda Agama Menurut Hukum Positif dan Hukum Islam, Bandung: Refika Aditama.

Soekanto, Soerjono. (1983). Faktor-Faktor Yang Mempengaruhi Penegakan Hukum, Jakarta: Rajawali.

Pasal 1 ayat (6) PerMA No 02 Tahun 2003, Tentang Prosedur Mediasi di Pengadilan. 


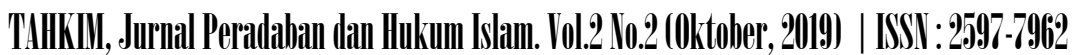

